\title{
ANALISIS SEMIOTIKA KEKERASAN TERHADAP ANAK DALAM FILM EKSKUL
}

\author{
Ismail Sam Giu/Susilastuti Dwi N/ Basuki \\ Jurusan Ilmu Komunikasi FISIP UPN "Veteran" Yogyakarta \\ Jl. Babarsari No. 2 Tambakbayan Yogyakarta 55282, Telp. (0274) 485268
}

\begin{abstract}
This research to aim for knowing the representation symbol's of children abuse on the Ekskul movie, and than for knowing the ideology's meaning what was gived from this movie. Kind of this research is a qualitative interpretive research by using the analysis of semiotic method. The analysis of semiotic method is a research method to learn the questions of sign, until the sign give the means of something. This research used the analysis semiotic by Roland Barhes. The point of Barthes theory is order of signification. Barthes devide by two order of signification, denotation meaning and contation meaning. The file analysis is a explain descriptive of explorative aspect to represent and explain the phenomenon. The test of file validitation using source triangulation by interview the trusted informan, to confirm the analysis in this research.

Founded from research result and by explained the all indicator below, finded the representation of Ekskul movie bring the ideology's meaning from his producer, that is the message against of violent. Ekskul movie try to be aware us that's the children abuse is exist and still going in our social life. Conscious it or not, like it or not, thats stil doing by the parents, teachers or the friends. Representation the symbol's of violent is variation. That's like striking stroke, ill-treatment, dressing-down, discrimination, let a way, and sexual violent.
\end{abstract}

Key words : ideology, sexual violent

\section{Pendahuluan}

Berbicara mengenai film tidak terlepas dari sejarah perkembangan film itu sendiri. Film ditemukan dari hasil pengembangan prinsip prinsip fotografi dan proyektor. Film pertama kali diperkenalkan kepada publik Amerika Serikat adalah The Life of an American Fireman dan film The Great Train Robbery yang dibuat oleh Edwin S. Porter pada tahun 1903 (Hiberty, Ungurait, Bohn dalam Ardianto dan Erdiyana 2004: 134).

Untuk perfilman di Indonesia sendiri, film pertama berjudul “Lely Van Java” yang diproduksi di Bandung pada tahun 1926 oleh David. Disusul oleh "Eulis Atjih" produksi Krueger Corporation pada tahun 1927/1928 dan sampai dengan tahun 1930 masyarakat pada waktu itu bisa menonton film-film berikutnya yaitu "Lutung Kasarung", "Si Conat" dan "Pareh". Film yang disajikan masih merupakan film bisu, dan orang-orang yang mengusahakannya adalah orang - orang dari Belanda dan Cina (Effendy, 2003 : 217).

Kehadiran film tidak dapat dilepaskan dari dunia realitas. Dalam banyak kasus, film dianggap menjadi cermin bagi masyarakat untuk membentuk kebudayaannya. Film sengaja dihadirkan untuk mencerminkan realitas itu sendiri. Artinya, apa yang digambarkan dalam sebuah film merupakan referesentasi dari dunia nyata.

Bukti film sebagai cermin dari realitas dapat kita lihat dari pengaruh film bagi khalayak. Film yang baik tentunya akan berpengaruh baik pula terhadap khalayak, sebaliknya film yang memberikan akibat buruk bagi khalayak, maka secara sadar atau tidak, akan menjadi sebuah memori budaya bagi masyarakat itu sendiri. Psycholog Amerika Serikat, Profesor Spiegel (dalam Onong Effendy, 2003 : 208-209) menyatakan bahwa 
pembunuhan dan kekerasan di Amerika Serikat secara luas dicerminkan oleh film, baik yang dipertunjukan di gedung bioskop maupun yang disiarkan di TV. Keterangan Prof. Spigel ini disampaikan dalam suatu simposium di Universitas Stanford California Amerika Serikat mengenai sebab musabab banyak digunakannya kekerasan oleh orang-orang yang tak bertanggungjawab. Kesimpulan simposium di Universitas Stanford itu ialah bahwa film yang dipertunjukan di gedung bioskop atau TV merupakan sumber-sumber pendidikan bagi masyarakat Amerika Serikat, untuk meniru-niru menjalankan kekerasan dalam kehidupan sehari-hari di Amerika Serikat.

Bukti film yang menjadi cerminan dari realitas dapat kita simak dari film - film sejarah, film dokumenter serta film yang diangkat dari kisah-kisah nyata dalam kehidupan sehari-hari. Dari sekian banyak film - film Indonesia yang ada, filmEkskul merupakan salah satu contoh film yang mereferesentasikan dunia realitas. Film yang meraih gelar Film Terbaik dalam Festifal Film Indonesia (FFI) 2006 ini, mengusung tema kekerasan yang dialami oleh seorang anak baik dirumah maupun di sekolah.

Kehadiran filmEksul ini turut menyadarkan kita semua bahwa di sekitar kita masih sering terjadi berbagai aksi kekerasan terhadap anak. Kekerasan terhadap anak ini hadir dalam berbagai bentuk, di antaranya kekerasan anak dalam rumah tangga oleh orang tua, kekerasan guru di sekolah pada muridnya dan atau kekerasan antar sesama pelajar sekolah. Bukti sahihnya dapat kita simak dari apa yang diberitakan Kompas edisi 21 Januari 2006 yang lalu, bagaimana Indah Sari yang baru berumur tiga setengah tahun dan Lintang yang berumur 11 bulan, tewas dibakar oleh ibunya sendiri. Dalam kasus lain, Eka Suryana yang berumur tujuh tahun, tewas dibunuh Ibu tirinya.

Kekerasan terhadap anak juga terjadi di sekolah dengan pelaku utama guru dan teman sekolah. Bentuk kekerasan itu beragam, mulai dari fisik, psikis hingga seksual. Namun, karena kekerasan dilakukan ditempat yang lebih terbuka, kekerasan di sekolah lebih mudah dicegah dibandingkan kekerasan di rumah.

Dari hasil penelitian Riyanto Adi, Peneliti Universitas Katolik (Unika) Atma Jaya Jakarta, menemukan banyak kasus kekerasan terhadap anak di sekolah masih saja terjadi. Provinsi yang tinggi tersebut adalah di Jawa Tengah, Sulawesi Selatan dan Sumatera Utara.

"Lebih dari 80\% guru melakukan kekerasan dalam bentuk fisik, seksual, dan emosional. Desember 2005 hingga Maret 2006. Secara khusus, kami meneliti anak - anak di 12 SD dan SLTP di tiga provinsi tadi," katanya dalam seminar Sekolah Ramah Anak yang diseleng-garakan oleh Depdiknas bersama Unicef, Komisi Perlindungan Anak Indonesia dan Save the Children, di Jakarta, Rabu (22/3). Sebagaimana dilansir dari Jurnalnet.com yang diakses tanggal 2 July 2007 (http://www.jurnalnet.com/konten.php?nama $=$ BeritaUtama\&topik=5\&id=714).

Dalam sebuah diskusi yang bertajuk "PeranAparat Penegak Hukum dalam Penanganan Kekerasan Seksual Terhadap Anak", terungkap fakta bahwa adanya penerapan Undang-undang No.23 Tahun 2002 tentang Perlindungan Anak, dianggap belum mampu melindungi dan mengakomodir hak-hak anak secara keseluruhan.

Dalam diskusi itu, Komisaris Murnila SH, Kepala Unit Ruang Pelayanan Khusus (RPK) Kepolisian Daerah Metro Jaya mengatakan "Kami sudah menggunakan Undang-Undang Perlindungan Anak (ketika membuat berkas perkara), tetapi jaksa tidak mau. Lebih memilih memakai undang-undang hukum pidana. Kalau pakai Undang-Undang Perlindungan Anak kan ada hukuman minimalnya untuk pelaku sehingga ada efek penjera untuk yang lain. Kami sudah bekerja capai-capai, tetapi antara penyidik dengan jaksa dan hakim belum ada persepsi yang sama," (Kompas, 20 Desember 2004).

Fakta-fakta yang diuraikan di atas merupakan contoh kasus bagaimana kekerasan terhadap anak ada dan masih sering terjadi di masyarakat kita. Kondisi yang oleh Nayato F. Nuala coba dihadirkan melalui pendekatan dan prespektif film. Film Ekskul dihadirkan sebagai pernyataan antikekerasan dari Nayato.

Berdasarkan uraian di atas, maka yang menjadi rumusan masalah dalam penelitian ini adalah, bagaimana representasi simbol - simbol kekerasan terhadap anak digunakan dalam film Ekskul? Penelitian ini bertujuan untuk (1) Menge- 
tahui bagaimana simbol - simbol digunakan sebagai tindakan kekerasan terhadap anak dalam filmEkskul, (2) Mengetahui makna pesan ideologis yang ingin disampaikan dalam film Ekskul.

Dalam penelitian ini penulis menggunakan konsep pemikiran dari Roland Barthes. Penelitian ini akan mencoba memahami tanda atau simbol simbol kekerasan dalam film Ekskul dengan menggunakan model pertandaan (Order of signification) yakni bagaimana tanda yang dihadirkan dipahami melalui pemahan denotasi dan konotasinya Roland Barthes.

Roland Barthes merupakan orang yang pertama kali menyusun model sistematis untuk menganalisa negosiasi dan gagasan makna interaktif. Inti teori Barthes adalah gagasan tentang dua tatanan pertandaan (order of signification) (Fiske, 2006:118). Dalam teori order of signification ini, Barthes membagi dua tatanan bagaimana tanda itu bekerja. Pada tatanan pertama, Barthes mengistilahkan dengan istilah denotasi, yakni konsep awal yang melekat pada tanda tertentu. Pada tatanan kedua, Barthes membedakannya menjadi tiga cara kerja tanda yakni konotasi, mitos dan simbolik.

(1). Denotasi, Tatanan pertandaan pertama adalah landasan kerja Saussure. Tatanan ini menggambarkan relasi antara penanda dan petanda di dalam tanda, dan antara tanda dan referenya dalam realitas eksternal. Barthes menyebut tatanan ini sebagai denotasi. Hal ini mengacu pada anggapan umum, makna jelaslah tentang tanda. Denotasi merupakan reproduksi mekanis di atas film tentang obyek yang ditangkap kamera; (2). Konotasi, Dalam istilah yang digunakan Barthes, konotasi dipakai untuk menjelaskan salah satu dari tiga cara kerja tanda dalam tatanan pertandaan kedua. Konotasi menggambarkan interaksi yang berlangsung tatkala tanda bertemu dengan perasaan atau emosi penggunanya dan nilai-nilai kulturalnya. Ini terjadi tatkala makna bergerak menuju subjektif atau setidaknya intersubjektif: ini terjadi tatkala interpretant dipengaruhi sama banyaknya oleh penafsir dan obyek atau tanda. Konotasi adalah bagian manusiawi dari proses ini; ini mencakup seleksi atas apa yang masuk dalam bingkai ( $\mathrm{rra}$ $m e$ ), fokus, rana, sudut pandang kamera, mutu film, dan seterusnya. Denotasi adalah apa yang difoto, sedangkan konotasi adalah bagaimana memfotonya; (3). Mitos, Cara kedua dari tiga cara Barthes mengenai bekerjanya tanda dalam tatanan kedua adalah mitos. Barthes menggunakan mitos sebagai seorang yang percaya dalam arti yang orisinal. Mitos adalah cerita yang digunakan suatu kebudayaan untuk menjelaskan atau memahami beberapa aspek dari realitas atau alam. Bagi Barthes, mitos merupakan cara berfikir dari suatu kebudayaan tentang sesuatu, cara untuk mengkonseptualisasikan atau memahami sesuatu; (4). Simbolik, Barthes (1977) juga menunjuk cara ketiga penandaan dalam orde ini. Dia mengistilahkan dengan simbolik. Sebuah obyek menjadi sebuah simbol tatkala simbol itu berdasarkan konvensi dan penggunaan, maknanya mampu untuk menunjukan sesuatu yang lain.

\section{Metode Penelitian}

Penelitian ini adalah penelitian kualitatif interpretatif yaitu penelitian yang datanya dinyatakan dalam keadaan sewajarnya atau sebagaimana adanya, dengan memaparkan cara kerja yang bersifat sistematik, terarah dan dapat dipertanggung jawabkan, sehingga tidak kehilangan sifat ilmiahnya. Penelitian kualitatif ini berdasarkan atas pendekatan interpretif (subjektif) konstruktivis.

Pendekatan subjektif muncul karena mengganggap manusia berbeda dengan sesuatu benda. Manusia dianggap bebas dan aktif dalam berperilaku dan memaknai realitas sosial. Realitas sosial merupakan hasil interaksi antar individu. Pandangan subejektif menekankan penciptaan makna, artinya individu-individu melakukan pemaknaan terhadap segala perilaku yang terjadi. Hasil pemaknaan ini merupakan pandangan manusia terhadap dunia sekitar (Kriyantono, 2006 :53).

Data primer diperoleh langsung dari penelitian melalui cara observasi terhadap obyek penelitian. Dalam penelitian ini peneliti menggunakan observasi tidak langsung, observasi dilakukan dengan menyimak film Ekskul karya sutradara Nayato Fio Nuala. Data sekunder diperoleh melalui sumber-sumber lain yang dikumpulkan dari berbagai sumber. Peneliti mengumpulkan data-data yang mendukung penelitian dari 
berbagai sumber seperti, buku, koran, majalan dan Obyek penelitian ini adalah film Ekskul karya Nayato Fio Nuala dalam bentuk VCD (video compact disk).

Analisis teks yang dipakai peneliti adalah bersifat kualitatif, yang merupakan proses penyederhanaan data kedalam bentuk yang mudah untuk dibaca dan dipahami. Film alat utama mengkaji objek penelitian diperoleh dengan mengkosumsi film. Penelitian ini merujuk pada metode analisis semiotika Roland Barthes. Inti teori Barthes adalah gagasan tentang dua tatanan pertandaan (order of signification). Dalam teori Order of signification ini, Barthes membagi dua tatanan bagaimana tanda itu bekerja. Pada tatanan pertama, Barthes mengistilahkan dengan istilah Denotasi, yakni konsep awal yang melekat pada tanda tertentu. Pada tatanan disitilahkan dengan konotasi, konsep mental yang melekat pada tataran sistem pertandaan.

Dalam penelitian ini tidak memaparkan suatu peristiwa atau kejadian yang tidak menjelaskan hubungan dan tidak membuat hipotesa tetapi hanya mengembangkan dan menjelaskan konsep, fakta dan data yang terhimpun dan disajikan dalam bentuk verbal yang menekankan pada persoalan kontekstual. (Rakhmat, 2004 : 24)

Dalam penelitian ini, teknik analisis data yang digunakan penulis adalah sistem konotasi dan denotasi Roland Barthes. Kata konotasi berasal dari bahasa latin "conotare", yang menjadi tanda dan mengarah pada makna-makna kultural yang terpisah/berbeda dengan kata dan bentuk-bentuk lain dari komunikasi. Kata konotasi melibatkan simbol - simbol, historis dan hal - hal lain yang berhubungan dengan emosional (Berger, 2000:15).

Berbeda dengan konotasi di mana penanda dan petanda berkaitan dengan nilai-nilai budaya, denotasi menunjukan arti literatur atau eksplisit dari simbol/ tanda yang ada. Denotasi menggunakan makna dari tanda dan sebagai definisi secara literal atau nyata. Denotasi dan konotasi menguraikan hubungan antara signifier dan signified.

Dalam penelitian ini, interpretasi pada film akan dibagi menjadi dua tahap yaitu :

Pertama, dengan mengelompokkan data berdasarkan indikasi-indikasi yang berkaitan dengan representasi kekerasan terhadap anak, khususnya pada komponen aktif dalam bahasa visual, kemudian menganalisa makna dalam film yang bersifat menjelaskan melalui elemen-elemen film seperti tokoh, lokasi, tingkah laku dialog dan musik.

Kedua, merumuskan analisis yang telah dilakukan pada tahap pertama. Scene yang dipilih dalam analisis nantinya yaitu melalui tahapan pemilihan potongan - potongan adegan dalam film. Sebuah adegan adalah kumpulan dari shot yang dibagi menjadi bagian-bagian dari keseluruhan cerita film.

Analisis kekerasan dalam film Ekskul ini fokus pada dua tokoh utama dalam cerita, yakni Joshua dan Sabrina. Meski memiliki latar belakang keluarga serta mengalami kekerasan yang berbeda, namun kedua anak ini memiliki kecendrungan yang sama, yakni tertekan oleh kondisi lingkungan mereka. Bagaimana representasi simbol-simbol kekerasan yang terjadi pada kedua tokoh ini, serta makna pesan yang ingin disampaikan oleh sutradara dari keduanya menjadi pusat kajian dan penelitian ini Pada akhirnya seluruh elemen dari makna yang terdiri dari, simbol dan ikon senantiasa akan dikonstruksikan ke dalam konversi. Proses tersebut merupakan kerja ideologis, karena konversi tidak dirumuskan di ruang hampa. Proses konstruksi inilah yang akan dijadikan basis deskrpsi terhadap obyek kajian.

Validitas atau pensahihan data yang akan digunakan peneliti dalam penelitian ini adalah metode Triangulasi. Melihat atau meneliti sesuatu hal dari posisi atau sudut pandang yang berbeda untuk mendapatkan hasil yang akurat merupakan intisari dari metode ini.

Dalam penelitian ini lebih fokus pada model triangulasi sumber yaitu dengan membandingkan dan mengecek derajat kepercayaan suatu informasi yang diperoleh melalui waktu dan alat yang berbeda dalam penelitian kualitatif. Untuk itu peneliti akan menganalisis data dari obyek penelitian dengan tiga sudut pandang yang berbeda, yaitu :

Pertama, dari interpretasi dari peneliti. Sudut pandang ini akan berisi penafsiran penafsiran peneliti dari berbagai simbol dan tanda - tanda yang digunakan oleh sutradara film tersebut. Peneliti juga akan memperhitungkan tentang frame - frame, teks - teks, dialog - dialog 
serta musik yang digunakan. Kedua, sudut pandang dilihat dari artikel - artikel yang bisa didapat dari koran, majalah, buku, hingga menggunakan situs - situs pencari di Internet. Ketiga, akan diambil dari wawancara praktisipraktisi film yang ada diseputar kota Yogajakarta.

\section{Hasil Penelitian dan Pembahasan}

Setelah mengumpulkan dan mengelompokan data berdasarkan indikasi-indikasi yang berkaitan dengan representasi kekerasan, maka tibalah peneliti untuk merumuskan data kedalam analisis semiotika. Berikut adalah beberapa Scene film yang merepresentasikan kekerasan yang dialami Joshua dalam lingkungan keluarganya.

Film ini menggambarkan bagaimana tokoh sentral dalam film ini mengalami kekerasan di lingkungan keluarga maupun di sekolah. Misalnya, dalam salah satu scene dimana menggambarkan pemukulan yang dialami Joshua di keluarganya. Pada tataran denotasi, bapak, ibu serta Joshua sedang makan malam di meja makan. Suasana tampak hening dan kaku. Tidak ada percakapan di antara ketiganya. Ayah dan Ibu Joshua tampak serius menyantap hidangan malam mereka, hingga Joshua merasa ia tidak nyaman dan tidak dihiraukan, oleh sebab itu Joshua memilih untuk pergi meninggalkan bapak dan ibunya yang sedang makan. Namun ayah Joshua yang melihat gelagat itu, menyuruh Joshua untuk menghabisi makannya, Joshua beralasan bahwa dirinya tidak lapar. Didesak terus oleh ayahnya untuk menghabisi makanan, Joshua memakan makannya dengan "rakus" hingga akhirnya ayah Joshua menanparnya diiringi dengan kalimat "dasar anak kurang ajar!!".

Dalam shot awal pada film ini diambil dengan menggunakan tehnik high angle shot (HAE), hal ini dimaksudkan untuk memberi gambaran yang jelas tentang kondisi meja makan lengkap dengan menu makanannya. Selebihnya, tiga shot lainnya diambil dengan gaya medium shot (MS), hal ini untuk bisa memberi gambaran yang jelas terhadap elemen-elemen dalam film baik latar, situasi, adegan dan tokoh-tokoh yang berperan.

Pada tataran konotasi, pemukulan yang dilakukan oleh ayah Joshua terhadapnya menggambarkan bagaimana posisi orang tua yang terkadang bersifat otoriter terhadap anaknya. Hal ini menyelipkan kecendrungan bahwa orang tua lebih banyak melihat kesalahan anak tanpa melihat lebih jauh sebab musabab perilaku itu muncul. Padahal kekeliruan utama bukan pada perilaku kekurang ajaran Joshua terhadap orang tuanya, melainkan terletak pada bagaimana pola komunikasi antara anak dengan orang tua yang berjalan tidak baik, sehingga anak merasa tidak nyaman dan betah untuk berlama-lama bersama dengan kedua orang tuanya. Kebringasan Joshua dalam memakan makanannya lebih menggambarkan bagaimana Joshua menunjukkan kekesalannya terhadap apa yang selama ini ia rasakan, perasaaan ketidak nyamanannya dan kekecewaan atas perilaku kedua orang tuanya.

Secara umum hal ini telah membuktikan bagaimana telah terjadi pergeseran nilai budaya dan minimnya mutu komunikasi antar manusia yang berujung pada miskinnya budaya komunikasi. Oleh karenanya, manusia tidak lagi diposisikan sebagai subjek pengguna bahasa, melainkan obyek tanda di tengah-tengah kehidupan bermasyarakat. Bahasa sehari-hari yang dianggap komunikatif dalam konteks ini telah berubah wujud kedalam ekspresi verbal berjuluk kekerasan, teror, kebrutalan dan kriminalitas.

Hal ini juga tampak jelas dalam masyarakat kita. Bagaimana Siti Ihtiyatus Soleha, tujuh tahun, disetrika oleh ayahnya sendiri. "Aksi kekerasan terhadap anak ini terjadi di Sunter Jaya, Tanjung Priok, Jakarta Utara. Korbannya bernama Siti Ihtiyatus Soleha atau biasa disapa Tia yang belum genap berusia 8 tahun. Korban mengalami luka bakar di kedua kaki dan tangannya, akibat ditempeli setrikaan panas oleh ayah kandungnya sendiri, Johandi. Beruntung setelah diobati di Rumah Sakit Griya Medika Sunter, Tia kemudian sudah diperbolehkan pulang" (Sumber: http:// news.indosiar.com/news_read.htm?id=48273, diakses tanggal 2 Juni 2007)

Dalam masyarakat, anak masih sering cenderung dipandang sebagai milik orang tua, sehingga di satu sisi tindakan kekerasan terhadap anak seperti mendapat permakluman dan toleransi serta dipandang sebagai bagian dari pendidikan yang memang merupakan kewajiban orang tua. Selain itu, tindakan kekerasan terhadap anak 
secara umum juga lebih dipandang sebagai masalah internal keluarga, sehingga relatif menjadi tabu untuk dibicarakan secara lebih terbuka.

Keluarga atau rumah tangga adalah fondasi primer bagi perkembangan, kepribadian dan tingkah laku anak. Keberhasilan keluarga (orang tua) dalam membentuk watak anak sangat tergantung pada subjek-subjek dalam keluarga tersebut. Orang tua sebagai subjek terpenting dalam keluarga tersebut, semestinya dapat mendidik anak dengan penuh kasih sayang dan kelembutan. Anak sebenarnya juga memiliki hak untuk dapat menikmati suasana hangat dalam keluarga, sehingga ia dapat mengembangkan potensi dirinya secara lebih sempurna. Kesadaran tentang hak-hak anak dan efek buruk kekerasan terhadap anak masih menjadi sesuatu yang cukup langka di masyarakat kita. Bentakan, tamparan, pengurungan, ataupun penelantaran, dipandang dalam kerangka pendisiplinan anak.

Pada tataran denotasi, Joshua difitnah oleh teman - temannya di sekolah bahwa ia yang mengancam membunuh Jerry. Faktanya ia tidak merasa melakukannya. Mendengar hal itu, Ibunya menyuruh Joshua untuk ke psikiater. Ayahnya turut menanyakan alasan Joshua mengancam teman teman sekolahnya. Karena merasa tidak melakukannya dan terus didesak oleh orang tuanya, Joshua memilih untuk mati jika harus kepsikiater. Mendengar ucapan Joshua itu, ayahnya langsung

Gambar 1 Kekerasan dalam bentuk pemukulan yang dialami Joshua di lingkungan keluarga.

Tampak pada gambar Joshua diinterogasi dan dipukuli ayahnya.

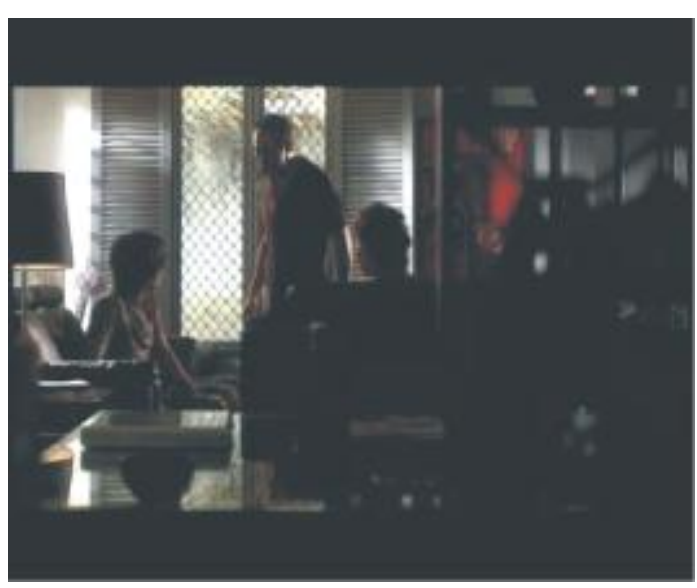

Ayahnya menginterogasi Joshua soal ancamannya terhadap anak - anak basket

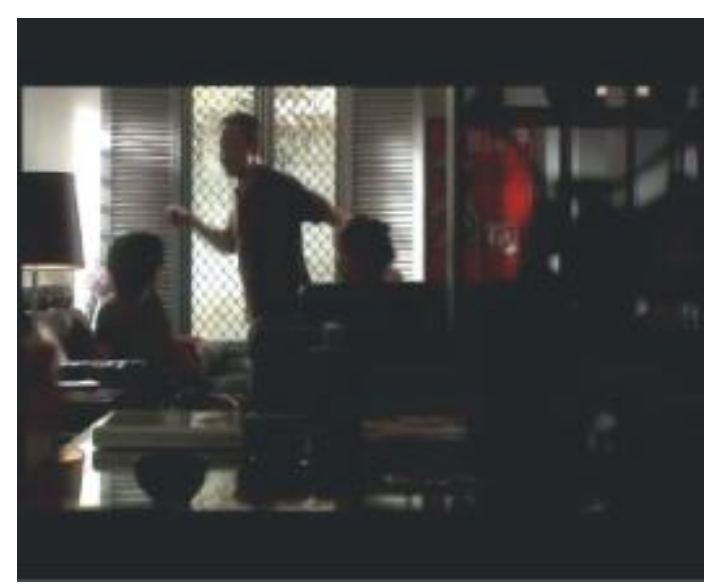

Ayahnya menampar Joshua diikuti dengan kata - kata "iya lebih baik kamu mati saja!"

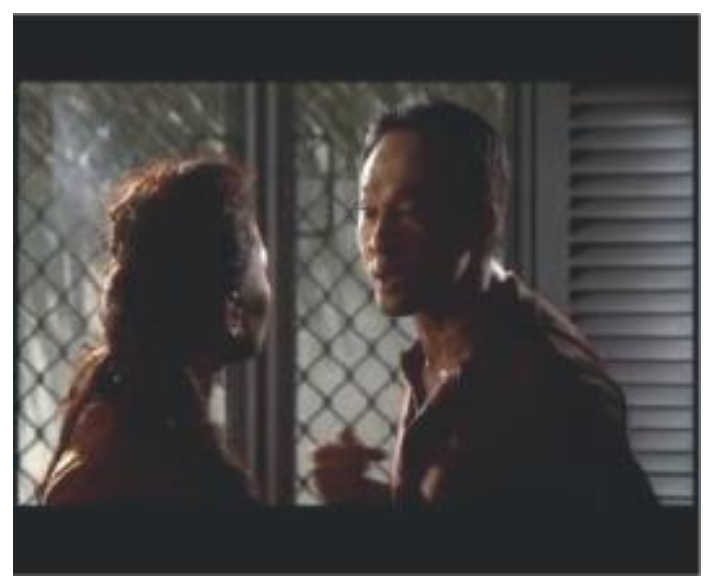

Ibunya membela Joshua, terjadi dialog antara ibu dan ayahnya 


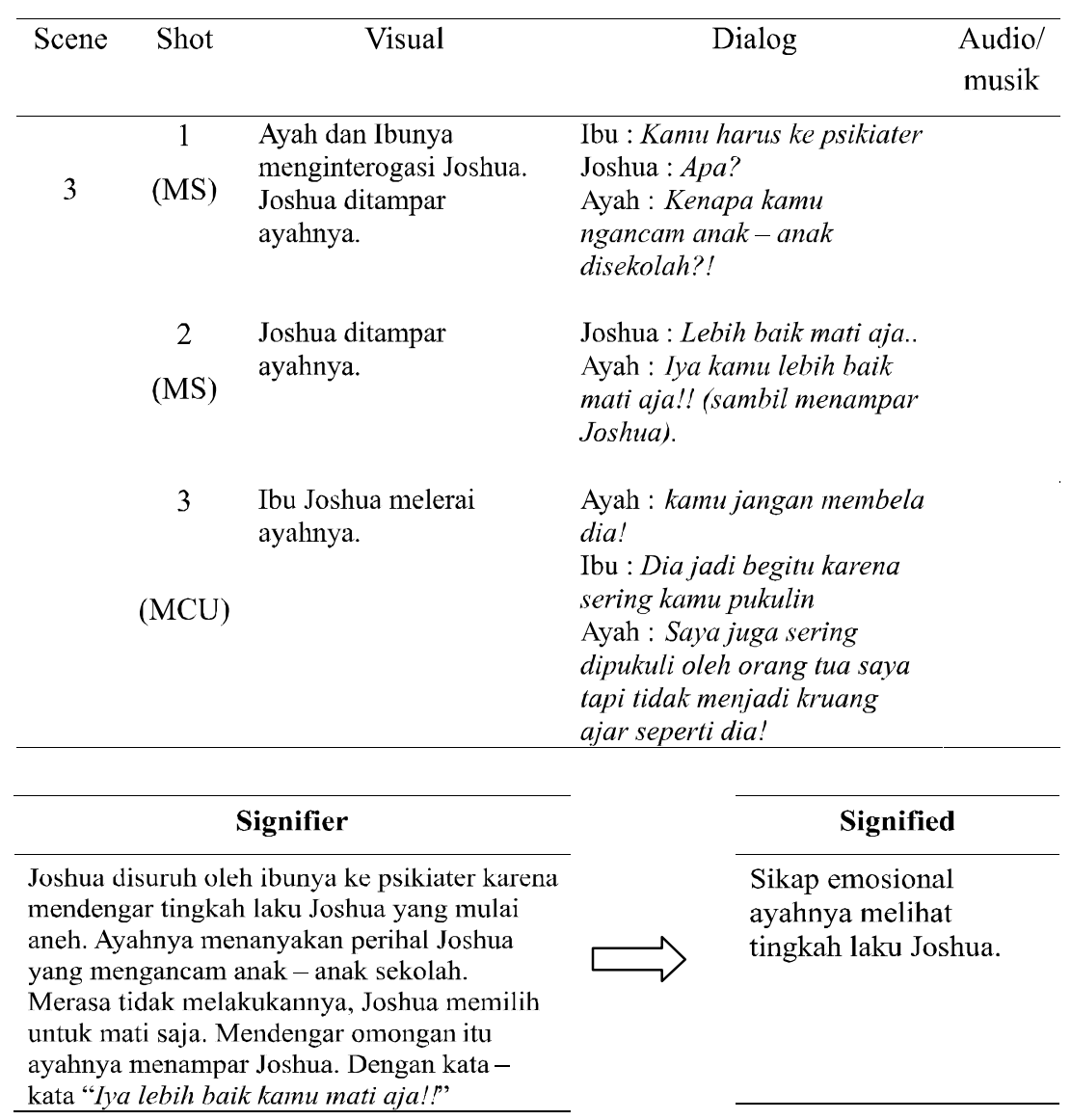

naik pitam dan memukuli Joshua sambil mengeluarkan kata - kata "Iya kamu lebih baik mati!!".

Untuk tataran konotasi, kata - kata yang diucapkan oleh ayah Joshua "saya juga sering dipukuli oleh orang tua saya tapi tidak menjadi kruang ajar seperti dia!" menggambarkan bagaimana tindak kekerasan kepada anak telah menjadi semacam pola asuh yang membudaya secara turun temurun dalam keluarga. Seorang anak yang sering mendapat perlakuan kasar dari ayah, maka secara langsung atau tidak pola-pola pengasuhan itu akan ditiru untuk generasi selanjutnya.

Senada dengan penjelasan di atas, Abu Huraerah (2006:42) menyebutkan bahwa salah satu dari empat faktor penyebab kekerasan terhadap anak adalah pewarisan kekerasan antargenerasi. Menurutnya, banyak anak belajar perilaku kekerasan dari orang tuanya dan ketika tumbuh menjadi dewasa mereka melakukan tindakan kekerasan kepada anaknya. Dengan demikian, perilaku kekerasan diwarisi (transmitted) dari generasi ke generasi. Studi-studi menunjukkan bahwa lebih kurang 30 persen anak - anak yang diperlakukan dengan kekerasan menjadi orang tua yang memperlakukan kekerasan kepada anaknya.

Pada konteks kekinian, terjadinya kekerasan terhadap anak dalam keluarga penyebabnya adalah rapuhnya tatanan keluarga. Karakteristik tatanan keluarga yang rapuh menurut Abu Huraerah (2006 :58), adalah ketidakmampuan orang tua dalam mendidik anak dengan sebaik-baiknya, yaitu tiadanya perhatian, kelembutan, dan kasih-sayang dari orang tua terhadap anak. Ruang keluarga yang dihiasi oleh suasana pertengkaran, perselisihan dan permusuhan adalah sumber terjadinya kekerasan fisik dan yang paling terkena sasaran kekerasannya adalah anak.

Hal lain yang menarik adalah, kata - kata "lebih baik mati saja" yang diucapkan Joshua. Ini dapat peneliti tafsirkan sebagai pernyataan frustasi yang diucapkan oleh anak yang teraniaya. Mati baginya dapat menyelesaikan permasalahan secara instant.

Kejadian ini terasa sangat relevan bila kita menyimak berbagai aksi bunuh diri yang dilakukan oleh anak - anak di kalangan masyarakat kita. 
Contoh kasus bagaimana Yudianto, umur 12 tahun, siswa SDN 1 Karangtengah, Kecamatan Ampelgading, Pemalang, ditemukan tewas gantung diri di dalam rumahnya sendiri. (Sumber : http:// www.suaramerdeka.com/harian/0408/04/ nas06.htm) diakses 12 Juni 2007.

Kekerasan ini tidak saja dirasakan Joshua dalam lingkungan keluarga, tetapi juga kekerasan yang sering ia terima dari teman temannya disekolah. Berikut adalah beberapa Scene yang merepresentasikan kekerasan dalam lingkungan sekolah :

Pada tataran denotasi, Joshua digantung oleh Jerry di depan pintu pagar Sekolah. Teman teman sekolah yang melihat kejadian itu, hanya menertawakan dan mengolok-ngolok Joshua. Joshua hanya bisa menangis, menahan rasa sakit dan malunya atas perlakuan teman - teman sekolahnya.

Pada tataran konotasi, Joshua tidak saja mengalami tindak kekerasan fisik dari teman temannya melainkan juga kekerasan secara psikis, yakni kekerasan yang ditimbulkan dari penghardikan dan penyampaian kata - kata kasar dan kotor, termasuk di dalamnya dengan menertawakan dan mengolok - olok Joshua. Hal ini

Gambar 2 Kekerasan fisik dan psikis yang dialami Joshua di lingkungan sekolah.

Tampak pada gambar bagaimana Joshua digantung di pagar sekolah.

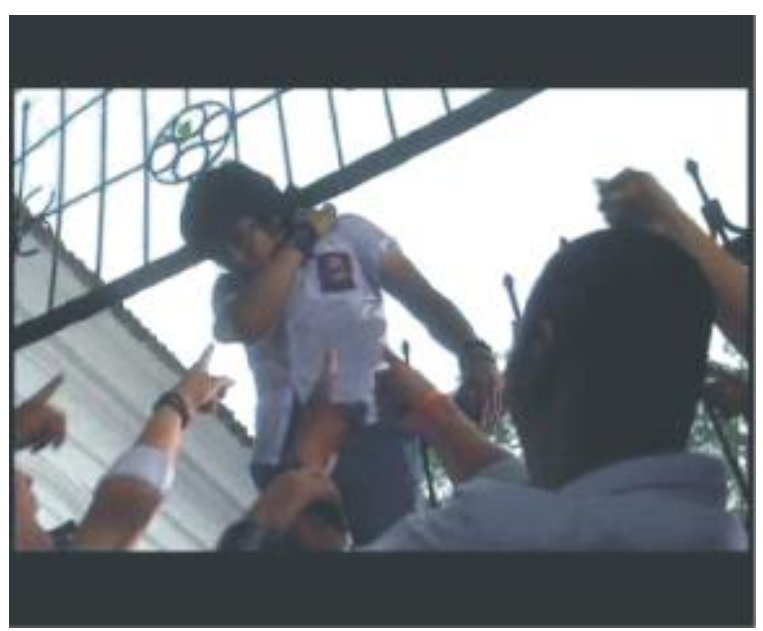

Joshua digantung di pagar sekolah. Tampak Jerry dan teman - temannya mengolok ngolok Joshua.

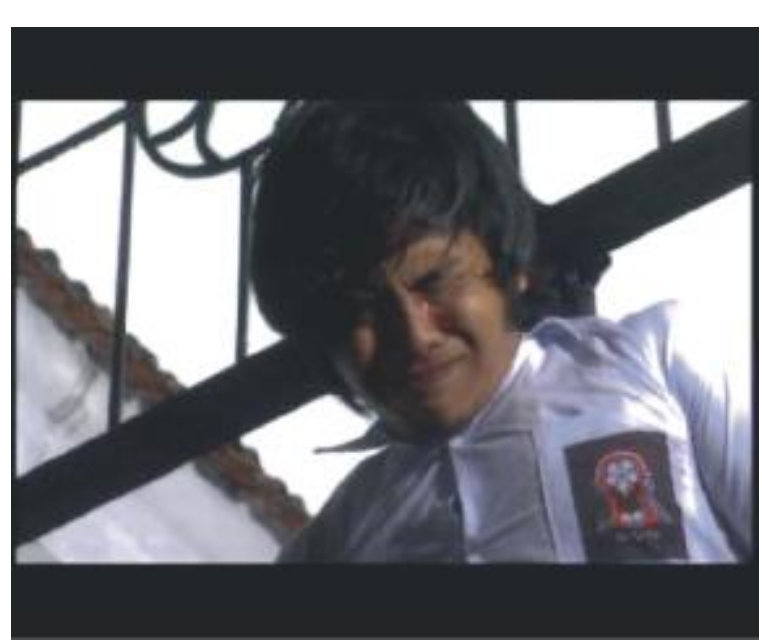

Ekspresi kesedihan Joshua

\begin{tabular}{cclcc}
\hline Scene & Shot & \multicolumn{1}{c}{ Visual } & Dialog & \multicolumn{1}{c}{ Musik } \\
\hline 4 & $1(\mathrm{MS})$ & $\begin{array}{l}\text { Joshua digantung di pagar } \\
\text { sekolah oleh Jerry dkk, dan } \\
\text { ditertawakan oleh teman }-\end{array}$ & Bit musik sedih \\
& & & \\
& & teman sekolahnya. & Bit musik sedih \\
& Joshua menangis Manahan & & \\
\hline
\end{tabular}

\section{Signifier}

Joshua digantung di pintu pagar, ditertawakan serta diolok olok oleh teman - temannya.

\section{Signified}

Kekerasan fisik dan psikis serta kemerosotan moral anak - anak. 
merupakan kemerosotan moral anak. Indikasi ini dapat dilihat dari tindak kekerasan yang dilakukan oleh Jerry dkk dengan menggantung Joshua di pintu pagar sekolah, tidak lagi dimaknai sebagai sebuah kekerasan terhadap orang lain melainkan sebagai sebuah lelucon (joke) yang pantas untuk ditertawakan dan diolok-olok.

Tehnik pengambilan gambar Extreme Medium Shot (EMS) ketika Joshua sedang digantung, lebih menonjolkan perasaan Joshua ketika itu. Bagaimana ia menangis, malu dan menahan rasa sakit yang ia derita. Bit musik yang mengalun lambat dan sendu menggiring perasaan penonton untuk turut merasakan apa yang dialami oleh Joshua.

Dalam film ini kekerasan sekolah juga tampak dalam scene yang menggambarkan Joshua di pukul oleh teman-temannya di sekolah. Pada tataran denotasi, Joshua oleh Jerry, Matius dan Mack digiring ke toilet sekolah. Dengan mencekik mulut Joshua, Jerry mengancam Joshua bahwa di sekolah mereka tidak ada Jagoan lain selain dirinya. Untuk mempertegas itu Jerry menampar pipi Joshua. Kekerasan itu belum berakhir, ketika Jerry hendak keluar toilet, Matius juga turut ambil bagian dengan memukuli perut Joshua. Efek buram ketika matius memukul turut disertakan dalam adegan ini.

Pada tataran konotasi, telah terjadi kekerasan ganda pada Joshua. Selain kekerasan psikis/mental yang dideskripsikan dengan ancaman oleh Jerry Matius dan Mike, Joshua Juga dipukuli oleh Matius. Yang menarik adalah Efek Buram pada adegan pemukulan Matius kepada Joshua. Efek dalam adegan ini sengaja sutradara tampailkan sebagai pesan moral, bahwa tindakan pemukulan/penganiyaan antara sesama pelajar bukan merupakan tindakan yang terpuji dan tidak dapat dibenarkan. Efek dalam adegan ini menjadi penekanan pesan tersebut.

Masih mengambil lokasi syuting yang sama, yakni toilet sekolah, Joshua mengalami perlakukan kekerasan dari ketiga teman kelasnya, yakni Jerry Matius dan Mike. Pada tataran konotasi, adegan ini menggambarkan kekerasan yang dialami Joshua yang sedang berada di toilet sekolah. Ketika itu Joshua sedang buang air kecil. Tidak lama berselang Jerry, Matius dan Mike ketiganya tiba-tiba masuk. Jerry menyuruh Matius untuk masuk kedalam toilet, Matius mengintip Joshua yang sedang buang air kecil. Pada adegan ini, efek buram turut disertakan. Pada Shot lain, Jerry dan Matius memasukan kepala Joshua kedalam toilet disertai dengan kalimat, masukin!!, Mampus Loe!!.

Pada tataran denotasi, kembali Joshua mengalami tindakan kekerasan dari teman - teman sekolahnya. Kali ini tidak saja kekerasan berwujud fisik, tetapi juga berwujud kekerasan seksual. Hal ini terlihat dari adegan dimana Matius mengintip Joshua yang sedang buang air. Efek buram kembali ditampilkan yang bisa kita maknai sebagai warning bahwa perilaku tersebut tidak terpuji dan tidak dibenarkan.

Adegan yang sangat relefan dengan kisah tewasnya Edo Rinaldo, siswa SD kelas dua yang dianiaya empat temannya di toilet sekolah. Bagaimana Edo dianiaya dengan dipukuli dan diinjak di toilet sekolah. Yang lebih ironisnya lagi, Tiga dari empat pelaku penganiayaan tersebut adalah perempuan teman sekelasnya. (Sumber : http://www. metrotvnews.com/berita.asp?id=38173, diakses tanggal 2 Juni 2007).

Kekerasan yang dialami anak tidak hanya dari aspek fisik tetapi juga aspek psikologis. Kekerasan dari aspek psikologis juga dialami oleh siswa-siswa di sekolah. Film Eskul menggambarkan betapa sekolah seringkali bukan tempat yang aman bagi anak didik. Beberapa scene dari film ini menggambarkan hal itu. Salah satu bentuk kekerasan psikologis diperoleh tokoh sentral film ini yaitu dikucilkan oleh teman-temannya. Pada tataran denotasi, Joshua sedang melintas di teras sekolah. Teman teman sekolahnya menertawakan dan mengolok - olok dirinya. Dalam shot lain teman-teman yang lain coba menghidari Joshua. Joshua hanya bisa pergi sambil menahan rasa malu. Joshua dihindari oleh teman - teman cewek dan dipandang sebagai orang "aneh" yang harus dihindari.

Pada tataran konotasi, Joshua mengalami perlakuan yang tidak mengenakan dari teman temannya. Menertawakan dan mengolok - ngolok Joshua dalam konteks ini bisa peneliti maknai sebagai tindakan kekerasan mental yang dialami oleh Joshua sehingga ia merasa tertekan secara 
psikologis dan sosial.

Selain tindak kekerasan yang dilakukan oleh teman - temannya Joshua terhadap dirinya, tindak kekerasan ini juga terjadi dan dilakukan oleh guru disekolahnya. Tindak kekerasan ini menjelma dalam tindak diskriminasi dan ketidakpedulian kepala sekolahnya terhadap Joshua. Hal ini tampak jelas dari dialog berkut ini :

Miranda : Joshua dipukuli oleh tim bola basket termasuk Jerry

Amanda : Itu tuduhan berat bu', saya harap ibu punya bukti

Miranda : Saya tidak punya bukti tapi menurut bu ratih..

Ratih : Iya ibu kemarin saya liat Johua sembunyi kesakitan, dia dipukilin

Amanda : Ibu yakin?

Ratih : Tidak bu, dia bilang dia jatuh

Amanda : Berarti dia jatuh bu, dan itu bukan bukti kalau Jerry yang melakukannya

Ratih : Tapi bu, Joshua akhir-akhir ini berubah.. dulu dia ranjin, pintar dan ngak mau ngurusin urusan orang lain. Sekarang dia banyak bikin masalah, nilainya turun. Perubahan ini sudah cukup jadi bukti bu..?

Amanda : Bukti apa bu? Maaf tapi tidak mungkin Jerry yang membuat Joshua menjadi berubah. Jerry datang dari keluarga baik-baik dan mereka sangat memperhatikan keluarga kita

Miranda : Mungkin saja maksud sumbangan itu untuk nutupin kenakalan anak- nya bu?

Amanda : Apa?! Sudah, kalau kalian punya bukti saya mau dengar, kalau tidak, permisi saya sibuk!

Pada tataran denotasi, ibu Miranda (guru BP Joshua) didampingi ibu Ratih menemui kepala sekolah (ibu Amanda) untuk melaporkan pemukulan yang dilakukan oleh Jerry dan anggota tim bola basket. Ibu Miranda berasumsi bahwa Joshua dipukuli oleh anak - anak bola basket termasuk Jerry. Hal ini berdasar atas perlakuan Jerry dan teman - teman basket yang selalu menganiaya Joshua. Sayang laporan ibu Miranda dan ibu Ratih ini tidak bisa dibuktikan karena Joshua mengaku ia tidak dipukuli melainkan jatuh. Ibu Amanda yang dikenal dekat dengan keluarga Jerry yang selalu membantu pihak sekolah membantah akan hal itu, ibu Amanda meminta ibu Miranda dan ibu Ratih untuk membuktikannya.

Pada tataran konotasi, terlihat diskriminasi dari pihak sekolah (terutama kepala sekolah) yang menaruh perhatian yang lebih terhadap salah satu anak didiknya dibandingkan dengan anak didik yang lain. Hal ini disebabkan oleh berbagai hal, di antaranya faktor orang tua murid yang memiliki jabatan terhormat ataupun kedekatan secara materil dengan pihak sekolah.

Diskriminasi ini bisa dikatergorikan sebagai sebuah tindakan kekerasan. Kekerasan yang lahir dari strukrur refresif dan tidak adil dari pihak penguasa (dalam konteks ini adalah pihak sekolah), akibatnya akan membawa kemerosotan derajat anak karena tidak memiliki keabsahan untuk mengungkapkan, merealisasikan serta mengem-

\begin{tabular}{l}
\hline \multicolumn{1}{c}{ Signifier } \\
\hline Ibu Miranda sebagai guru BP \\
Joshua didampingi Ibu Ratih \\
menemui kepala sekolah (Ibu \\
Amanda) untuk melaporkan \\
pemukulan yang dilakukan \\
oleh Jerry dan anggota tim \\
bola basket. \\
Ibu Amanda membela Jerry \\
dan mengabaikan laporan bu \\
Miranda dan Ratih \\
\hline
\end{tabular}

\begin{tabular}{l}
\hline \multicolumn{1}{c}{ Signified } \\
\hline Diskriminasi oleh kepala \\
sekolah terdahap Joshua. Hal \\
ini dikarenakan Keluarga \\
Jerry yang sering memberi \\
bantuan kepada pihak sekolah
\end{tabular}


bangkan diri secara lebih leluasa. Anak akan merasa terisolir dan tidak mendapatkan perhatian yang sama dengan rekan-rekannya yang lain.

Dalamfilm Eskul ini kekerasan juga dialami oleh siswa perempuan. Meski tidak seekstrem dengan apa yang dialami oleh Joshua, namun ternyata apa yang dialami oleh Sabrina cukup membuat ia merasa tertekan dengan kondisi keluarga. Nasib membuat Sabrina merasa dekat dengan Joshua.

Dalam satu scene Sabrina dan Joshua bertemu di taman sekolah. Sabrina dan Joshua membicarakan nasib mereka yang ternyata memliki kesamaan.

Pada tataran denotasi, Sabrina dan Joshua akhirnya bertemu disalah satu taman, setelah sekian lama Sabrina terus membuntuti dan menyaksikan berbagai tindak kekerasan yang dialami oleh Joshua di sekolah. Dalam pertemuan itu, Joshua menanyakan maksud Sabrina yang terus membuntutinya. Sabrina mengatakan bahwa sebenarnya ia juga merasakan apa yang dirasakan oleh temannya itu, yakni rasa tertekan. Namun menurut Sabrina, rasa tertekan yang ia rasakan bukan dari teman - teman disekolahnya.

Pada tataran konotasi, antara Sabrina dan Joshua sebenarnya memliki kesamaan nasib, kedua-duanya tertekan oleh kondisi lingkungannya. Jika Joshua tertekan oleh kondisi keluarga dan sekolah, maka Sabrina tertekan oleh kondisi keluarganya. Kata - kata yang diucapkan Sabrina "mungkin Jos, dan bukan dari anak - anak disekolah" dapat peneliti maknai sebagai faktor penyebab lain diluar lingkungan sekolah, yakni keluarga. Kekerasan pada Sabrina dalam film ini memang tidak dihadirkan secara lugas sebagaimana yang dialami oleh Joshua. Namun, dalam beberapa scene peneliti menemukan indikatorindikator yang mampu mejelaskan mengapa Sabrina merasa tertekan dan mengapa faktor tertekannya adalah keluarga.

Pada tataran denotasi, Kapten Margono, ayah Sabrina, sedang bertugas untuk menghadapi kasus penyanderaan yang dilakukan oleh Joshua. Disaat meminta data Joshua kepada bu Miranda, Kapten Margono menanyakan jika bu Miranda mengenali Sabrina. Mengetahui bahwa Bu Miranda kenal Sabrina dan mengatakan bahwa Sabrina adalah anak yang rajin, Kapten Margono mencibir bibirnya sambil mengangguk.

Pada tataran konotasi, pertanyaan Kapten Margono kepada ibu Miranda apakah ia mengenal Sabrina, dapat peneliti maknai sebagai gambaran bagaimana seorang ayah tidak mengenali tindak tanduk anaknya dalam lingkungan sekolah. Dengan kata lain, tidak atau jarang memperhatikan perilaku Sabrina. Cibiran bibir dan anggukan kepala lebih menjelaskan bagaimana Kapten Margono baru menyadari perihal anaknya setelah mendengarkan tanggapan kepala sekolah Sabrina (ibu Amanda).

Hal ini sekaligus mencuatkan sebuah ironi. Bagaimana mungkin seorang ayah sebagai orang yang pertama dan orang terdekat dalam lingkungan pergaulan anak, tidak mengetahui perilaku anaknya sendiri, Anak yang ia besarkan dengan jerih payahnya? Penjelasan justru didapatkan dari guru sekolah dan dari sebuah momentum yang kebetulan berpapasan (tugas Kapten Margono di sekolah anaknya sendiri) Hal ini yang membawa kesimpulan bagi peneliti bahwa Sabrina jarang mendapatkan perhatian bahkan kasih sayang dari ayahnya.

Tidak jarang apa yang dikisahkan dalam adegan ini relevan dalam masyarakat kita. Bagaimana orang tua baik ayah maupun ibu, karena kesibukan tugas dan pekerjaannya sehari-hari, justru mengabaikan anak - anak mereka dengan dalih mencari nafkah untuk keluarga. Akibatnya waktu anak - anak untuk bermain, bercengkrama dan diperhatikan oleh orang tuanya semakin kecil, bahkan bisa jadi masa anak - anaknya dihabiskan ditangan kakek, nenek, paman, bibi hingga pembantu. Kondisi ini secara suka atau tidak, langsung atau tidak akan berdampak pada kondisi psikologis dan mental anak terutama terhadap hubungan antara orang tua dan anak.

Hal ini bisa dikategorikan ke dalam unsur kekerasan terhadap anak. sebagaimana dijelaskan pada bab- bab sebelumnya, bahwa konsep child abuse (kekerasan terhadap anak) tidak saja meliputi tindakan atau ancaman fisik secara langsung oleh orang tua atau orang dewasa lainnya, tetapi juga tindakan penelantaran kebutuhan-kebutuhan dasar anak atau sering disebut sebagai kekerasan sosial.

Pada tataran denotasi, terjadi proses dialog antara Sabrina dan ayahnya. Sabrina diminta 
untuk pulang ke rumah meninggalkan sekolah, lokasi penyanderaan yang dilakukan Joshua terhadap teman - teman. Sabrina menolaknya hingga ayahnya membentak Sabrina. Kapten Margono akhirnya menyuruh anak buahnya untuk menjaga Sabrina. Dengan nada mengejek, Sabrina menirukan ucapan ayahnya.

Pada tataran konotasi, Sabrina mendapatkan kekerasan psikis dari ayahnya. Kekerasan dalam wujud bentakan ayah kepada anaknya. Masalahnya sebenarnya sepele, ayah Sabrina menyuruhnya untuk segera pulang ke rumah. Hal ini mengindikasikan bagaimana pola komunikasi antara anak dan orang tua tidak berjalan dengan baik. Serupa dengan apa yang terjadi pada Joshua, Sabrina tampaknya dalam hal ini selalu mendapatkan bentakan dari ayahnya. Pola komunikasi orang tua dengan anak yang seharusnya berjalan penuh kelembutan dan kehangat, kini berubah menjadi bentakan. Hal ini bisa saja terjadi mengingat perangai orang tua Sabrina yang keras karena besar sebagai seorang perwira polisi. Tidaklah mengherankan apabila Sabrina akhirnya terbawabawa oleh pola-pola komunikasi ayahnya itu.

Hal menarik yang bisa ditangkap dalam adegan ini adalah bagaimana watak Sabrina yang berubah ketika berbicara atau berhadapan dengan ayahnya. Sabrina yang dikenal sebagai anak rajin dan pendiam disekolah tiba-tiba berubah menjadi nakal dan keras kepala kepada ayahnya. Hal ini setidaknya terbaca daribagaimana seorang perwira polisi yang ditugasi untuk menjaga Sabrina, langsung menyanggah perintah atasnya itu dan langsung direspon oleh Kapten Margono dengan kalimat "Iya saya tau! (sambil memalingkan wajah ke Sabrina), "kamu jangan ke mana-mana". Hal ini mengindikasikan bahwa Sabrina memiliki perangai yang nakal dan cenderung agresif didepan ayahnya, dan perilaku ini jangankan oleh ayahnya, polisi yang menjadi bawahan Kapten Margono pun menyadarinya.

Menariknya kemudian adalah, bagaimana relevansi antara Joshua dan Sabrina dalam hal ini? Terutama terhadap motivasi komunikator (sutradara) dalam menghadirkan peran Sabrina? Meski tidak memiliki peran dominan layaknya Joshua, kehadiran tokoh Sabrina dalam film ini memiliki peran yang besar untuk membentuk suatu rangkaian cerita dan melahirkan makna yang dalam. Hal ini setidaknya terlihat dalam adegan terakhir filmEksul, yakni adegan saat Joshua telah mati tertembus peluru pistolnya sendiri.

Sebagaimana diketahui, dari hasil penyelidikan polisi terhadap orang yang menjual senjata api, diketahui bahwa Joshua sebenarnya hanya memiliki satu butir peluru, peluru yang ia beli bersamaan dengan senjata api. Dalam proses penyanderaan, Joshua tercatat sekali telah melepaskan tembakan, tepatnya saat Kapten Margono mengancam akan masuk menyergap Joshua. Dengan kata lain, peluru Joshua telah habis.

Faktanya, peluru yang ada dalam pistol Joshua ternyata tindak hanya satu melainkan banyak, salah satu di antaranya tepat mengenai bagian kanan kepala Joshua. Tidak digambarkan kenapa dan bagaimana peluru yang terisi dalam psitol Joshua lebih dari satu. Namun jika kita teliti lebih jauh lagi, secara tersirat sebenarnya hal ini bisa kita pahami. Penyebab dari hal itu adalah berkat bantuan dan pemberian peluru dari Sabrina (yang notabenenya merupakan anak dari perwira polisi).

Peneliti sampai pada kesimpulan ini karena merujuk dari satu adegan yang ditampilkan, yakni adegan sesaat setelah Joshua menembak kapalanya sendiri. Dalam adegan itu digambarkan Sabrina dan Ayahnya saling berpandang-pandangan. Sabrina dengan ekspresi gugup dan kaget, sedangkan ayahnya dengan ekpresi kaget, tidak menyangka, dan tatapan curiga.

Inilah yang menjadi antiklimaks dari peran Sabrina sebagai seorang anak yang merasa tertekan, sama seperti Joshua. Jika efek dari perasaan tertekan Joshua adalah dengan bunuh diri, maka Sabrina tergambar dariusahanya membantu Joshua dengan memberikan peluru. Peluru yang tidak ia sangka malah justru membunuh Joshua.

Melihat uraian di atas, film dibangun dari manusia sebagai subjek dari kekuatan film tersebut. Film merupakan salah satu media komunikasi yang dapat berinteraksi, dimana penonton dapat merasakan perasaan iba, haru, marah, sedih atau lucu dari cerita film tersebut. Dalam teori komunikasi, film bisa dikatakan sebagai sebuah pesan yang disampaikan kepada komunikan. Makna tidak terdapat pada pesan melainkan pada penerima pesan. Bagaimana kreator mengurangi bias 
makna yang terjadi sehingga pesan itu bisa dipersepsi secara seragam itulah yang penting, kecuali jika film diangap barang seni yang cenderung susah dipahami dan lebih banyak menjadi familiar bagi kreatornya daripada audiencenya (Sobur, 2003 : 59).

Terkait dengan penguraian (interpretasi) makna di atas, dalam film penginterpretasian makna sangatlah beragam, bergantung dari orientasi nilai dan wawasan para pembaca/penonton sehingga komunikasi tersebut menjadi efektif. Efektifitas komunikasi sendiri bisa diukur secara berbedabeda tergantung seperti apa tujuan dari proses komunikasi itu sendiri. Bagaimana tanda dari komunikator itu dipersepsi oleh penerima (komunikan) sehingga terjadi komunikasi yang efektif.

Dalam sebuah kajian klasik, seperti yang dipaparkan Cooper dan Jahoda dalam tulisan mereka, "The Evasion of propaganda: How Prejudiced People Respond To Anti-prejudice Propaganda," sebagaimana dikutip Sobur (2003 :3), para peneliti menemukan bahwa sebuah serial kartun "Mr.Bigot" yang bertujuan mengurangi prasangka sosial, ternyata lebih banyak memperkuat prasangka ras ketimbang menguranginya.

Dikemudian hari, para peneliti lain mengamati akibat serupa pada serial televisi terkenal Amerika, All in ihe Family (Vidmar dan Rokeach dalam Sobur 2003 : 4). Produser eksekutif serial itu, Norman Lear, mencoba membuat tokoh utama, Archi Bunker, tampak seperti orang tolol. Lear menjelaskan bahwa para penonton yang berprasangka akan mengenali diri mereka dalam kelakar tolol Archie dan sebagai akibatnya akan mengubah perilaku mereka.

All in the Family pun lantas menjadi amat populer dan serial ini benar-benar mengobarkan kontroversi. Namun seperti halnya komik "Mr. Bigot," serial ini menghasilkan sesuatu di luar antisipasi produsernya. Bukannya terpukul oleh Archie, para penonton malah dengan kecendrungan seperti Archie merasa bahwa Archie sebagai orang yang bersahaja, jujur, rajin dan baik hati. Sebaliknya, para penonton yang menentang nilai - nilai Archie menganggapnya tolol, banyak tingkah, kaku, suka mendominasi, dan suka menganiaya.

Dari uraian di atas, jelas tergambar bahwa antara komunikator (sutradara/produser) dengan komunikan (penonton), terjadi semacam missed communication dalam menginterpretasi film, atau dalam kondisi lain, terjadi penafsiran yang beragam dari komunikan. Apa yang bisa kita petik dari kajian di atas adalah, bahwa penafsiran film $\mathrm{Mr}$.

Bigot dan Archie Bunker ditentukan oleh orientasi nilai dan wawasan penonton itu sendiri.

Penelitian ini merupakan salah satu cara bagaimana menginterpretasi dan mengurai makna yang terjadi dalam proses komunikasi, khususnya dalam kajian film. Hal ini dimaksudkan untuk mendapatkan pemahaman, yang setidak - tidaknya nyaris sama dengan apa yang diharapkan oleh komunikator.

Menjawab pertanyaan rumusan masalah dalam bab - bab sebelumnya, makna pesan ideologis apa yang ingin disampaikan komunikator dalam film ini? Berdasarkan hasil penelitian dan dengan menguraikan berbagai indikator-indikator diatas, ditemukan bahwa kehadiran film Ekskul di tengah - tengah masyarakat ternyata membawa suatu pesan ideologi tersendiri dari sutradaranya, yakni pesan anti kekerasan.

Film Ekskul mencoba menyadarkan kita bahwa selama ini ternyata ada dan dan masih sering terjadi kekerasan anak di masyarakat kita yang secara sadar atau tidak, suka atau tidak, dilakukan oleh orang tua, guru maupun teman sekolah/sepermainan. Representasi simbol - simbol kekerasan yang dihadirkan dalam film ini beragam, mulai dari kekerasan berupa pemukulan, penganiyaan, penghardikan/ kata - kata kasar, diskriminasi, penelantaran hingga kekerasan seksual.

Dalam kasus kekerasan yang dialami oleh Joshua di lingkungan kelurga, nampak bahwa orang tua, dalam hal ini ayahnya, sering memukuli Joshua sebagai upaya untuk mendidik anaknya. Mendidik Joshua dari sikapnya yang menghardik ibunya, mengancam anak basket di sekolah (meski bukan Joshua pelakunya), hingga sikap Joshua yang dianggap oleh ayahnya adalah salah.

Hal ini sekaligus memberikan gambaran kepada masyarakat kita, bahwa pendidikan dalam keluarga tidak jarang dibalut dengan kekerasan. Parahnya lagi, banyak di antara orang tua tidak menyadari akan hal itu. Tindakan mendidik model ini, dinilai semata - mata murni sebagai sebuah 
proses mendidik anak. Kenyataannya, model model pembinaan semacam ini tidak jarang membuat anak merasa tertekan, takut dan tertutup kepada orang tuanya, hingga rasa ketidaknyamanan dalam lingkungan keluarga.

Merunut berdasarkan waktu, model pendidikan anak dengan kekerasan ini sebenarnya telah berlangsung lama. Jika di zaman dahulu, konteks pembinaan model ini mendapatkan respon yang relatif positif dari anak, maka dalam konteks kekinian hal itu telah jauh berubah. Pada zaman dahulu, seorang anak yang dibina secara keras (pemukulan, penghardikan, dll) relatif bisa diterima anak sebagai sebuah proses pembinaan, kini hal itu sulit untuk diterima. Anak akan cenderung merasa tertekan, reaktif terhadap orang tua, bahkan menggap orang tua mereka sebagai seorang musuh yang harus dijauhi dan dilawan. Hal ini tidak terlepas dari berbagai pengaruh eksternal yang diterima anak, baik dari lingkungan maupun pola pikir serta wawasan anak yang kian berkembang.

Kecendrungan lain yang bisa ditangkap dalam film ini adalah bagaimana kekerasan yang sering dilakukan oleh ayahnya terhadap Joshua, ternyata juga sering dialamai oleh ayahnya ketika ia masih anak - anak. Dengan kata lain, model pengasuhan dengan kekerasan yang dilakukan oleh ayah Joshua diwarisi dari ayahnya (transmitted violence). Hal ini sejalan dengan pemikiran Richard J. Gelles yang mengemukakan bahwa faktor - faktor kekerasan terhadap anak terjadi akibat pewarisan kekerasan antar generasi, stres sosial, isolasi sosial dan keterlibatan masyarakat bawah, dan struktur keluarga. (Huraerah 2006 : 42).

Banyak anak mengalami dan belajar kekerasan dari orang tuanya dan ketika tumbuh menjadi dewasa mereka melakukan tindak kekerasan terhadap anaknya. Dengan demikian, perilaku kekerasan diwarisi (transmitted) dari generasi ke generasi. Studi-studi menunjukkan bahwa lebih kurang 30 persen anak - anak yang diperlakukan dengan kekerasan menjadi orang tua yang bertindak keras terhadap anak - anaknya. Sementara itu, hanya dua sampai tiga persen dari semua individu menjadi orang tua dan memperlakukan kekerasan kepada anaknya. Beberapa ahli yakin bahwa faktor yang mem-pengaruhi tindakan kekerasan di masa depan yaitu apakah anak menyadari bahwa perilaku tersebut salah. Anak yang yakin bahwa perilaku buruk dan layak mendapatkan tindakan kekerasan akan lebih sering menjadi orang tua yang memperlakukan anaknya secara salah, dibandingkan anak - anak yang yakin bahwa orang tua mereka salah untuk memperlakukan mereka dengan tindakan kekerasan. (Huraerah 2006 : 42)

Apa yang ada dalam film Ekskul ini hanyalah sepenggal kecil kisah dan kasus kekerasan terhadap anak yang tersaji dalam bentuk dan prespektif film. Kekerasan terhadap anak yang dilakukan oleh orang tua, guru hingga teman sekolah/sepermainan.

Keseluruhan aksi kekerasan dalam film ini seolah menggiring kita untuk melihat lebih jauh bagaimana aksi kekerasan itu terjadi dalam konteks realitas disekitar kita. Dari data yang diperoleh Komisi Nasional (Komnas) Perlindungan Anak (sebagaimana dikutip dari mediaindonesia.com) untuk tahun 2007 saja (selama Januari-April), terdapat 417 kasus kekerasan terhadap anak. Rinciannya, kekerasan fisik 89 kasus, kekerasan seksual 118 kasus, dan kekerasan psikis 210 kasus. Dari jumlah itu 226 kasus terjadi di sekolah. Untuk data tahun lalu (2006), menyebutkan kekerasan fisik 247 kasus ( 29 kasus di sekolah), kekerasan seksual 426 kasus (67 kasus di sekolah), dan kekerasan psikis 451 kasus (96 kasus di sekolah).

\section{Simpulan}

Berdasarkan uraian di atas, simpulan yang bisa diambil pertama, Sscara umum film Ekskul, terlepas dari anggapan adanya penciplakan musik film Korea, "Taeguki" (2005), Ekskul merupakan film yang sangat baik. Tema dari ide film ini orisinil, serta membawa pesan moril yang mendidik.

Kedua, film Ekskul merupakan film yang mengusung tema kekerasan terhadap anak. Kekerasan yang berdampak pada perilaku dan psikologis anak. Ketiga, representasi simbolsimbol kekerasan dalam film ini dihadirkan dalam berbagai bentuk dan varian, mulai dari pemukulan, penganiayan, penghardikan/kata-kata kasar, hingga pada kekerasan seksual. 
Keempat, hadirnya dua tokoh dan karakter yang berbeda, film ini terasa lebih variatif dan maksimal dalam menyampaikan pesan morilnya. Hingga sampai pada suatu titik dimana kekerasan, apapun bentuknya, akan berdampak pada perkembangan dan tumbuh kembang anak itu sendiri.

Mengingat film memiliki dampak yang cukup besar maka disarkan, pertama, untuk Insan film Indonesia agar ikut membangun Indonesia. Caranya dengan menghadirkan film - film yang mampu mendidik sekaligus menghibur bagi masyarakat Indonesia. Dengan adanya film yang mendidik, maka kita telah terlibat dalam proses perubahan perilaku dan pola pikir masyarakat ke arah yang positif dan lebih baik.

\section{Daftar Pustaka}

Ardianto, Elvinaro dan Erdiyana, Lukiati, 2004, Komunikasi Massa Suatu Pengantar, PT Remaja Rosdakarya, Bandung.

Berger, Arthur Asa, 2000, Media analysis Tehniques, Edisi kedua, Penerbitan Universitas Atma Jaya, Yogyakarta.

Budiman, Kris., 1999, Kosa Semiotika, LKiS, Yogyakarta.

Budiman, Kris, 2003, Semiotika Visual, Buku Baik dan Yayasan Cemeti, Yogyakarta

Effendy, Uchana Onong, 2003, Ilmu, Teori dan Filsafat Komunikasi, PT Citra Adi Karya, Bandung.

Fiske, John, 2006, Cultural and Communication Studies, Jalasutra, Yogyakarta.

Huraerah, Abu, 2006, Kekerasan Terhadap Anak, Nuansa, Bandung.

Imanjaya, Ekky, 2006, A to Z about Indonesian Film, PT Mizan Bunaya Kreativa, Bandung.

Irawanto, Budi, 1999, Film, Ideologi, dan Militer: Hegemoni Militer dalam Sinema Indonesia, Media Pressindo bekerjasama dengan Yayasan Adikarya IKAPI dan The Ford Foundation, Yogyakarta.

Jalaluddin, Rachmat, 2004, Metode Penelitian Komunikasi, PT Remaja Rosdakarya, Bandung.
Kriyantono, Rahmat, 2006 "Riset Komunikasi”, P.T Kencana, Jakarta.

Moleong, Lexy Ji, 1991, Metodelogi Penelitian Kualitatif, PT Remaja Rosdakarya, Bandung.

McQuail, Dennis, 1996, Teori Komunikasi Massa : Suatu Pengantar, Erlangga Jakarta.

Muhadjir, Noeng, 1996, Metodelogi Penelitian Kualitatif Edisi III, PT Remaja Rosdakarya, Bandung.

Mulyana, Dedi, 2005, Ilmu Komunikasi Suatu Pengantar, PT Remaja Rosdakarya, Bandung.

Purnaningtyas, Theresia Betty, 2003, Wanita Dalam Perspektif Film Indonesia (Analisis Semiotika Sosok dan Posisi Perempuan Dalam Film Pasir Berbisik dan Ca Bau Kan), Skripsi, Yogyakarta.

Sobur, Alex, 2003, Semiotika Komunikasi, PT Remaja Rosdakarya, Bandung.

Sobur, Alex, 2004, analisis Teks Media, PT Remaja Rosdakarya, Bandung.

Sumarno, Marseli, 1996, Dasar-dasar apresiasi film. Grasindo, Jakarta.

Windhu, I. Marsana, 1992, "Kekuasaan dan kekerasan: Menurut Johan Galtung”, Kanisius: Yogyakarta.

Zoest, Aart Van, 1993, "Semiotika : tentang tanda, cara kerjanya dan apa yang kita lakukan dengannya", Yayasan Sumber Agung: Jakarta.

\section{Koran}

Kompas, 20 Desember 2004

Kompas, 21 Januari 2006

\section{Internet}

WWW.jurnalnet.com

WWW.news.indosiar.com

www.suaramerdeka.com

www.metrotvnews.com

\section{Majalah}

Mediator. Vol 3 Tahun 2002 